\title{
POLICY IMPLEMENTATION OF WORKING CULTURE DEVELOPMENT IN MINISTRY OF RELIGIOUS AFFAIRS
}

\author{
Salma Munawwaroh ${ }^{1}$, Endang Larasati ${ }^{2}$, Sri Suwitri $^{3}$, Hardi Warsono ${ }^{4}$ \\ Diponegoro University, Faculty of Social and Political Sciences, Semarang, Indonesia \\ jenewa.alexandra@gmail.com, prodidap@gmail.com
}

\section{Original Scientific Paper doi:10.5937/jouproman8-24153}

\begin{abstract}
Indonesia as a religious state has the Ministry of Religious Affairs who has a vision and mission in realizing the Indonesian communities are obedient, harmonious, intellectually intelligent, emotional and spiritual as well as prosperous born inner. However, ironically, the ministry that should be the front guard of this morality, in 2012 was the ministry with the lowest perception index version of Corruption Eradication Commission known as $K P K$, and in 2014 the only ministry with the value of self under the standard of Corruption Eradication Commission known as KPK. Ministry of Administrative and Bureaucratic Reformhas published a regulation No. 39 in 2012 on guidelines for the development of work culture fo ministries and institutions in 2012. Thim research
\end{abstract} aims to identify and analyze the olicy implementation of working cult develop ent of based on regulation Numb 39 Ministry of Religious o ars and io tify factors affecting the imp nen on of do lopment policy of The Mistry of $\mathrm{R}$ vious Affarrs. This research is qualitative study sing descriptive analytica echniqu The findings in this study, the Minis Religious Affairs have not

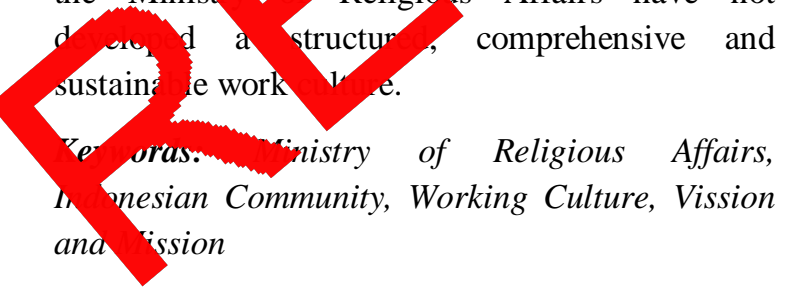

\section{INTRODUCTION}

The bureaucracy reform in Indonesia has begun from 2010. There are eight areas of change in bureaucracy reform, namely: Organization, regulatory law, huma apparatus, supervision acd ntability public service, $\mathrm{w}$ dset and or $g$ culture. One areg of har is the mindset and the $\mathrm{cy}^{\prime}$ are of rk ( $\mathrm{w}$ aset and culture c). chango mindset and culture of work has a strategic role in ganizing bureau acy for the better. ccording to the Grand Design reaucracy reform 2010-2025, in the wàm II namely year 2010-2014, bureaucracy in Indonesia has become a free government of corruption, collusion and nepotism known as $K K N$, the quality of public services are increasing and capacity at once Improved performance accountability.

The Ministry of Religious Affairs has a duty to conduct governance in religious fields. The vision of the Ministry of Religious Affairs is the realization of the Religious Society of Indonesia, peace, intelligent, and prosperous born inward in order to realize Indonesia's sovereign, independent, and personality based on the foundation of communally. However, ironically, the institute gets a black note about corruption. 
In 2012, the Ministry of Religious Affairs was established as a ministry with the lowest perception index of Corruption Eradication Commission version, and in 2014 is the only ministry with self-value under Corruption Eradication Commission standardization(KPK, 2015).

From the side of the public complaint, from 2015 to 2017 there was a significant increase annually as shown in table below.

Table 1 Community Complaint at the Ministry of Religious Affairs 2015-2017

\begin{tabular}{|c|c|c|}
\hline No & Years & Amount \\
\hline 1 & 2015 & 61 \\
\hline 2 & 2016 & 295 \\
\hline 3 & 2017 & \\
\hline
\end{tabular}

Source: Data from Ministry of Religious Affairs (16 Mej 18)

The Ministry of Religious Affairs as a religious institution with the lowest integrity became contrary to (Lerner, 1982)opinion of the religious influence on the undisputed manifestations of morality. In addition, spirituality important to reveal the inner and learn recognize the impact that spirituality on professional a pe onal lives of individuals(S. R bins n1.3) Malik stated that th is a gnificant positive relation $p$ between piritual intelligence and organizational performan (Malik \& Tariq, 2016)(G nan- 1, Hashim, \& Ismail, $20 \mathrm{~m}$ Tho ore, the with religiosity and eligio bac $r$ ad and the Ministry of Rel immmanmairs should be holy titutions mat uphold integrity as a un rsal core value.

In 2012, Ministry of Administrative and Bureaucratic Reformhas issued guidelines for the development of the work culture and institutions. In addition, revised in 2012 with the Regulation of Ministry of
Administ

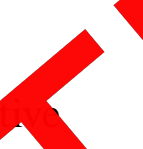

ano areaucratic Reform vumbe 39 in 20 \% were aimed at as the deve vment of the culture of ork in the implementation of bureaucracy form. sell as assisting n. istries/ stitutions and local govermments to encourage changes in the atumdes and behavior of officials and employees in their respective environment, and provide guidance on planning, implementing and monitoring as well as evaluating the implementation of the development of work culture.

The study of implementation is to understand what the real thing happens after a program is declared valid or formulated, while the focus of policy implementation attention, are events and activities arising after the dismissions of the State policy guidelines, which include both efforts to administrate it and to create real consequences/impacts on society or events(Sabatier \& Mazmanian, 1980). 


\section{LITERATUR REVIEW}

The problem of this this research issues are as follows:

1. How is the implementation of a working culture of development policy in the Ministry of Religion?

2. What factors do influence the implementation of the development of culture work in the Ministry of Religion?

\section{Policy Implementation}

Policy implementation in principle is a way that a policy can achieve its objectives. There is no more and no less. In order to implement public policy, two options exist, namely implementing in the form of a program or through a formulation of derivation policies or derivatives of these public policies. The implementation of a series of policies can be clearly observed, namely starting from programs to projects and activities. Implementation studies have a focus o work programs, operational activities o policy devices and resource allo tion (Denzin \& Lincoln, 2000) or org szing and leadership to achie poh jectrmm (Nugroho Riant 2017). 'n the implementation study nalyzes of the conformity policy imp nentation with guidelir and procedures should be (Sugivono 4).Hoy to realize policies, ow in ve ople to respond to polic á(Jodi \&, stephanie, 2015).

\section{Development Policy of Working} Gulture

The policy of working culture development is set on the Regulation of Ministry of Administrative and Bureaucratic Reform Number39 in 2012. The goal of this policy is the creation of the mindset and the working culture of the
State apparatus into a culture that develops the attitude and behavior of the outcomeoriented outcomes gained from the productivity of work and high performance to provide service to the community.

The transformation in working culture applies from the highest level to the smallest unit. The success of cultural change is determined by organizational leader behavior. Ministries and institutions are expected to create and develop organizational cultures that are mianted towards improved performar throu training, work unit of work k evaluatio and personnel, sou lizatio brenchmarking an rearnip labos es. The developm at ork culture is a systematic ort to im emer the values and norms of thical wo of the State ap mans and im fe implementation of governance tasks ind service to the community. The work c. ure is srmed from values that have been'monsistently agreed and have been so -lized in the environment of ministries/institutions as well as the internalization results expressed in the conduct of daily work in each employee. The internalized work culture can be seen from the work ethic shown.

The fundamental principle of work culture is the culture of work derived from the organizational culture, the result of the internalization process of organizational values expressed in the behavior of daily work. Culture of work is a mental attitude developed to always look for repairs, enhancements or improvements to what has been accomplished, the work culture is developed with the teachings of religion, Constitution, social and cultural conditions, and change of working culture should go on the planned. 
A structured, comprehensive and sustainable system with a precise and consistent strategy, the work culture implanted or transformed through organizational values changes.

The task of changing the mindset and developing a working culture in Ministry of Administrative and Bureaucratic Reformenvironment and the local government is the responsibility of the bureaucracy reform teams in each ministry/institution in particular the change management team. The development of work culture requires three major phases, namely the formulation of values, implementation and evaluation monitoring.

The formulation of a value consists of five steps, namely 1) planning, 2) identifying the value, 3) identifying the sensitive area, 4) Assigning the main behavior and 5) formulating how to measure the main behaviour. $\mathrm{Tl}$ implementation consists of as follows 1 Declaration of Value, 2) Pha man the soisalization and internaliz on th ugh communication. Manito ing mimmond evaluation to obsery now mu progress of the work atur of dev pment process is.

3. Th Fac is Affecting The Imply cation Of Cultural D elop ent ork on various previous journals mulated researchers there are four fac is that affect the implementation of cultural development, namely communication(Arianto, Zauhar, \& Hanafi, 2015)(Sani, Mohammed, Misnan, \& Awang, 2012)(Crews, 2013)(James, 2014)(Warrick, 2017)(Van der Voet, 2014)(Signé, 2017)(Bang, Kusuma， \&
Utomo, 2014)(Hanaysha, 2016)(Hill, 2003). The second was resources (Signé, 2017)(Mattila, 2008). The third was commitment and leadership (Sani et al., 2012)(Smith, 2003)(Yuan \& Lee, 2011)(Signé, 2017)(Hill, 2003)(Crews, 2013). And fourth was organization cultural value (Hill, 2003)(Zainuri, 2016)(Wihantoro, Lowe, Cooper, \& Manochin, 2015)(Yaghi \& Al-Jenaibi, 2018).

\section{A. Communication}

Communication on this dy used $t_{\text {. }}$ theory of implementation of ( $\downarrow$ ver III $\&$ Worley, 2006), accon ing to (Lav r IIV Worley, 2006, i (W odo, 2007)commv cation was jrotated calssify a s o "the pro of delivering communicator information to the c crmunticable". formation on public olicy accopling to (Lawler III \& Worley, 06) in Nidodo, 2007) need to be con muni a ed to policy perpetrators so hat policy players can know what they should prepare and do to run the policy so that the objectives and policy objectives can be achieved in accordance with the target (Widodo, 2007).This theory stated classify as follows that policy communication has many dimensions, such as transmition dimension, clarity and consistency.

i. The dimension of transmission demanded that public policy be delivered not only to the implementation of policies but also to the target groups of policies and other parties concerned either directly or indirectly. Before an official can implement a decision, he must realize that a decision has been made and an order for its implementation has been issued. 
The most important is how a policy stakeholder's readiness knows and understands the policy that has been made by the center and transfigured it into various forms of implementation and clear standards of operational procedures so that the executor can carry out its duties as policies implementation that have been issued. Signings of regulatory context of a policy becomes very important for the implementation of the program.

ii. The dimensions of clarity would require that if the policies are implemented as desired, then the policy executor should not only accept the instruction manual, but also the communication of the policy should be clear. Often the instructions forwarded to the executor are blurred and do not specify when and how a program is implemented. The obscurity of th communication message witk respect to the policy imp ation will encourage inc inect interpretation

the meanip of the original message.

iii. The ard dimen $n$ of policy c smunic ion is consistency. If the in ementation of the policy yants tak place effectively, the executio orders must be consistent ancrmmar. Although the commands presented to the policy executor have elements of clarity, but if the order is contradicted then the order will not facilitate the policy executor to perform its duties properly. On the other hand, the commands of inconsistent policies will encourage executor to take very loose actions in interpreting and implementing policies. When this happens, it will result in the ineffectiveness of the policy implementation due to the extremely loose actions that are likely not to be used to implement policy objectives

\section{a. Resources}

In government organizations as a public organization, the implementing organization that administicmmm the administrative policy must hay a resou. consisting of: "Staff, Informatio Authority Facilities" (Lawler III Worley, 2006) (Kadarisman, Gunay n, \& Is yati, ' $).$

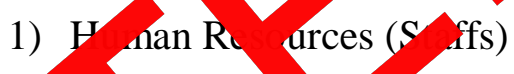
Lplen ntation o. policy will not succeed $\mathrm{w}$ hout the support of human resources afficient quality and qua ty. The quality of human ress fces is related to skill, urication, professionalism, and competence in the field, while the concern concerning the amount of human resources is enough to cover the entire target group. Human resources are very influential in the success of implementation, because without human resources that reliability of human resources, implementation of policies will run slowly.

\section{2) Budgetary}

In the policy implementation, the budget is related to the adequacy of capital or investment in a program or policy to guarantee this policy implementation, because without the support of a crowded budget, the policy will not run effectively in Reach goals and objectives. 
3) Facilities

Facility and infrastructure is one of the factors that influence the implementation of the policy. Procurement of decent facilities, such as buildings, land and office equipment will support the success of the implementation of a program or policy.

4) Information and Authority

Information is also an important factor in the implementation of policies, especially relevant information and enough about how to implement a policy. While authority plays a crucial role to assure and guarantee that, the policy is implemented according to the desired.

\section{b. Commitment and Leadership}

Commitment and leadership using the first Sabatier theory, the direction and ranking of the objectives at the priority scale of the office. Secondly, the ability of officials in realizing these priorities is namely, how to achieve objectives by deploying available resources(Sabatier \& Mazmanian, 1980).

\section{c. Organization Culture}

From the organizati al culture theory uses the Robbin cory o element of organizational cure froma $n$ s. Robbins, 2013)chsss d Organizàtion's founding rosophy, sele on, top managem an socializat

\section{Figure 1 How Organization's Culture Forn Source (S Robbins, 2013)}

\section{RES ARCH METHOD}

is st $y$ is a alitative study with an in- pth in cw method, observation no menmmentation. The analytical t. nniques used in this study are des ptive analytical techniques. Interviews conducted on the Minister of Religious Affairs as the supreme leader, central bureaucracy reform team and head of research and development of religious ministries, and and regions, 15 employees in the area.
IV. RESULT AND DISCUSSION

1. Implementation of Working Culture Development in Ministry of Religious Affairs

The Ministry of Religious Affairs is one of the ministries that are not in the autonomic. The Ministry of Religious Affairs also includes vertical institutions with a total of 4,543 units of work. 
Consists of 11 Echelon Unit 1 at the central Religious ministry, 34 provincial offices, 413 Office of the Ministry of Religious Affairs, 99 of the city's Ministry of Religious Affairs, 14Education and Training Centre, and 3 Research and DevelopmentHall, which amounted to 563 units of work. Meanwhile, for the unit of education that State status, consisting of: 1,690 Madrasah Ibtidaiyah Negeri (MIN), 1,444 Madrasah Tsanawiyah Negeri (MTsN), 765 Madrasah Aliyah Negeri (MAN), 11 Islamic State University (UIN). 32 State Islamic Institute ( IAIN), 14 state Islamic religious schools (STAIN), 1 State Catholic High School (STAKATN), 7 State Christian religious Colleges (STAKN), 1 Institute of Hindu Dharma Negeri (IHDN), 3 state Hindu High Schools (STAHN), 2 Buddhist colleges Of the State (STABN), a total of 3969 working units (Kementerian Agama RI, 2017a).

The Ministry of Religious Affair consists of 2,776 employees at the head office $(1.23 \%)$ and 223,184 sploy s in the area $(98.77 \%)($ Kemente on Ag a.RI, 2019).In 2014, the N Astry celigious Affairs declared fi lues of th vorking culture consint of: Integrity, (2) Profession sm, (3) Ih vvative, (4) Respon ilitie nd (5) Lead by example. Therformb on of th value is the result the ocus ro Discussionof Minister of $\mathrm{P}$ Ans Arairs with Echelon I and II n a consultant of ESQ named Ary Gn ndjar. The values formulated are the values required by the Ministry of Religious Affairs in conducting bureaucracy reform.

From the fifth phases of the formulation of value, the Ministry of Religious Affairs has gone through four processes i.e. 1) planning, 2) identifying value, 3) identifying the sensitive area, 4) establishing the main behaviour, but the Ministry of Religious Affairs past the fifth stage is Formulates how to measure key behaviors.

\section{The Policy of Ministry of Religious Affairs about Working Culture Value}

Since 2014 was declared. Minister of Religious Affairs issued Decree of the Minister of Religious Affairs 2017 on change on decree Religio Minister No. 447 in 2015 abou Road Ma bureaucracy Refor of Min try Religious Affairs $20^{1}-2019$, wich contains five alues workin culture. Other po cies or ong the implementation trategy of the cultural $y$ aero work aro KMA Number 504 in 018 is relating to the agent for change in e Ministry foligious Affairs as well as thu Deci on of Ministry of Religious ffairs Number 536 in 2018 on the guìuelines for implementing bureaucracy reform in the Ministry of Religious Affairs.

From interviews with the bureaucracy reform team of the Ministry of Religious Affairs, the value of the work culture declared only a statement or mere. Because it does not has special thing of the Decision of Ministry of Religious Affairs that regulates working culture. According to the narrative minister of religious culture, work is not regulated because of its uncoercive nature. 


\section{Bureaucracy Reform in Ministry of Religious Affairs}

Religious ministers feel the size of working culture can be seen from the results of the evaluation of bureaucracy reform increasing annually. Ministry of Religious Affairs in 2018 obtained the value of 74.02, increased from 2017 that reached the value of 73.27 and in 2016 obtained the result with the value of 69.14 , in 2015 was at the number 62.28 and 54.83. The Ministry of Religious Affairs performance report still focuses on budget absorption(Kementerian Agama RI, 2019).

Bureaucracy reform in the Ministry of Religious Affairs from 2010 to 2017 structural was an additional task on personnel Bureau and Ortala Bureau. Only since the year, 2017 has been described as structural regulation that handles bureaucratic reform in the Ministry of Religious Affairs. In addition, to date, in addition to the Ministry of Religio Affairs, the task of the bureaucracy reform team in the provincial office and office of the district Ministry of Re gous fairs is an additional task.

In 2018 and $D^{\prime}$ 2019, po prmance reports there were no specific adgets regarding areaucracy in orm and the develop ent of a working culture(K rerian Agama RI, 2019). In gion off $s a^{r}$ district, offices have been ormed d, eaucratic reform teams. certhelesu, the tasks and functions have no ret run according to guidelines.

\section{Promotion System}

The process of appointment of officials in the Ministry of Religious Affairs has new implementing Merit system by way of open bidding on Echelon 1 and 2 since year 2018. However, merit system does not apply to Echelon 3 to 4 . According to the Minister of Religious Trade in the Ministry of Religious Affairs is the Causisticonly.

The Ministry of Religious Affairs has declared a cultural value of work, but does not refer to the Regulation of Ministry of Administrative and Bureaucratic Reform Number 39 in 2012 on the guidelines for development of culture work. This can be seen from the unimplemented system of measurement of work culture and atmategy that is fast and precis in implementation of the dev spment culture work.

The Ministry \& Relio as Affà was able to acces sureau ac refor the eval a of bu qu acy reform annually that pplied to the central F cloor I (11 ec Jon work units I) in ddition, the unit of work in the area under Ministry of Religious Affairs is 4,532 unu now.

that is affecting the implementation of cultural development work

\section{Communication}

Decree of the Minister of Religion No. 582 in 2017 on the amendment to the Decree of the Minister of Religious Affairs Number 447 in 2015 about Road Map bureaucracy Reform Ministry of Religion year 2015-2019 which contains 5 values of working culture. Decision of Ministre Religious Number 504 in 2018 about Agent for Change of Ministry of Religious Affairs and Decision of Ministre Religious No. 536 in 2018 about implementation guidelines of bureaucracy reform at the Ministry of Religious Affairs all framed in bureaucracy reform. 
From the research results, structural bureaucracy reform are only in the central Echelon I., Central Java Provincial Office has been established a bureaucratic reform team but only additional tasks. The results of interviews with the bureaucracy reform team in Demak District, to date there have been no programs executed, only the DECREE of the team to fulfill the application data of bureaucracy reform from the center.

From the transmission dimension, the minister's working culture policy that does not specifically issue of Decision of Minister of Religious and the detailed rules on the implementation of the cultural value of work will make the transmission process not well received by the implementers and policy objectives. From the dimensions of clarity, without clear guidelines, communication can be misunderstood by the communfishes.

As for the consistency side, the five values of the working culture that has been declared are not considered as one o; the assessment of personnel or of Ethics of the Ministr of Re jious Affairs. The absenc ol ratromm indicators and ins nents to nake an individual of Stule A varatus a s not have object and meas able standards in carr g out ive cultual values of work, ma in at difficult to do objective cess ent by cadership of the imple entation five cultural values of Kby ammante Apparatus individually. In do sloping the work culture required guid, ines and law enforcement, so the implementation of the development of the culture of planned work, structured with systematic, comprehensive and sustainable. Communication strategies may include as follows:
- Minister of Religious Affairs issued a policy on implementing and internalizing the value of the culture of work, so implementation is coercive and has an element of law enforcement with a clear reward system. Because during this five cultural values are the policy of the Ministry that cannot be confirmed by the required official documents, such as PMA documents, Decisison of Minister Religious, or other om inl documents related to he progra, of 5 cultural valy of th work.

- Internalizing with training

- Dey ping a asurem st system 2. Resources

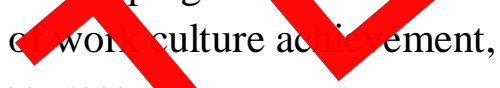

Development or the working culture Minist of Administrative and aucrat Reform Number 39 in 2012 and "acuree of the Minister of Religious Av irs No. 582 in 2017 was the task of the Management change of bureaucratic reform team. During the period 2010 until 2017 the reform team of the central Religious Ministry bureaucracy is an additional task, in the Central Java province bureaucratic reform team was formed in 2017, in Demak District bureaucracy reform team was formed in 2018. At the provincial and district level the bureaucracy reform team is still an additional task. From interviews, the district level of reform team did not yet have a program, and were formed based on the demands of applications launched by the central bureaucracy reform team. 
Since 2010 has established bureaucratic reform, and for 7 years focuses only on Echelon I, bureaucratic reforms are slow in the Ministry of Religious Affairs. This follows the publication of the Ministry of Religious Affairs and Decision of Minister Religious Number 536 in 2018 on the guidelines for implementing bureaucracy reform in the Ministry of Religious Affairs. Decision of Minister Religious Number 504 in 2018 about the change agent guidelines on the Ministry of Religion have not been implemented at the provincial or district level.

From an interview with bureaucracy Reform of the Ministry of Religious Affairs, Ministry of Administrative and Bureaucratic Reformteam did not control the Regulation of Ministry of Administrative and Bureaucratic ReformNumber 39 in 2012 on the guidelines for development of cultur work.

\section{Budgetary}

The policy will not ru effecti ly in achieving goals and compacted budget port. List Budget Implementation $(D I P$, tated that No budget ated to ork culture progran semen ian Agama RI, 2019).At egional and district level, ith" à york uni 8,532 units of work, educ on and aining in order to change adset anrumculture set apparatus depends on 4 training halls in Indonesia. This is because there is no budget in the framework of socialization and internalization of work culture in each unit of work.

The strategy taken in socialization and internalization is to communicate five cultural values of work on each activity to the audience as one of Standard Operating Procedure of activities in the Ministry of Religious Affairs.

\section{Facilities}

The facilities in implementing five cultural values in the Ministry of Religious Affairs are banners. In the selection of change agents, the bureaucratic reform team has created a computer-based application to facilitate the establishment of change agents. Currently it ha applied to all satkers, but pefully th application can facilitat the lection o agent changes in each nit of won

As the larmest ert al organization, the develop nt of w culty needs to be facili ced th work a laboratory. So that policies and strategies that are plied can run effo ively and efficiently.

1) Information and Authority

Relevant and adequate information are about how to implement a policy. While authority plays a crucial role to assure and guarantee that, the policy is implemented according to the desired. In terms of the development of the cultural work in the Ministry of Religious Affairs related information and authority, should the role of the Research and Development agency be empowered. Research on the culture of work will provide valid information regarding the achievement of work culture value. 
5. Commitment and Leadership

According to (S. Robbins, 2013), the existence of the leader will have an influence on (i) the value he wants to accomplish, (ii) the direction of the Organizationfuture, (ii) showing how the tasks are resolved. Position leaders in the process of achieving organizational objectives, therefore, associated with the behavior displayed, skills, knowledge and values. Research Data from the Research and Development Agency of the Ministry of Religious Affairs provides an overview that the leadership of each of the Ministry of religious work units has two opposite sides. Who need to get a record in the implementation of the program 5 (five) cultural value of work is the implementation of the merit system in terms of recruitment, placement and promotion of employees. These are who assessed not yet concerned about the competency aspect, resulting in employe who in a certain position has $n$ competency and disposing in the field (interview results with the ad the Ministry of Religious Affan Resea nand Development April27 (19).

First, the dir crom nd rankis of the goal is at th priority sc. of the office. And sec aly, the ability officials to realize $\mathrm{cb}$ priorities (Sabatier \& N num 980). cording to Nugroho, a top ecutiv this case the Minister of Re groummanffairs) who has been appointed i st bring a vision. The team they lead can nly be asked to provide inputs to decode the vision (Nugroho Riant, 2017).The Ministry of Religious Affairs has the vision of "the realization of the Religious Society of Indonesia, the pillars, intelligent and prosperous born inward in the framework of realizing the sovereign, independent and personality based on mutual cooperation"(Kementerian Agama RI, 2017b). One of the missions in fixing the bureaucracy is to realize clean, accountable and trustworthy governance. The objectives related to the improvement of the quality of the development of the field of religion is the implementation of the development of effective, efficient, transparent and accountable field of religion. Among others with: (a) the Defended Unexclusion Reasonable (WTP) in the opinion of Audit Board $Q^{f}$ MaOm ia known as BPK RI to the fina al report o the Ministry of Relio as Aairs; (b Increased results the Min ry of Religious Affairs p for nce repon, and (c) the risin of the $\mathrm{N}$ istry $\sigma^{\circ}$ Religious Affairs $o$ rel massess

results interviews with the inister of Religious Affairs, the supreme eader inte alized the five cultural values o. the ork by relying on the conscruasness of State Apparatus of Ninstry of Religious Affairs and not coercive. (Interview with the Minister of Religious Affairs, April 24, 2019), assumption of the Minister of Religious Affairs relate to culture work and code of ethics is something that is already built-in in State Apparatus, so that unpublished rules that bind apparatus concerning five cultural values of work and no budget Related to internalizing the value of working culture.

The Ministry of Religious Affairs as a ministry with the lowest corruption perception index in 2012, and the only ministry with the lowest self-value under the standard of Corruption Eradication Commission known as $K P K$ in 2014have a huge "task" in fixing the 4543 units. 
Development of work culture as a strategy change mindset and culture set will not run without planning, programmatic, systemic, comprehensive and sustainable.

\section{Organizational Culture}

Robbin stated that organizational culture created by some elements of the organization's founding philosophy, selection and top management ( $\mathrm{S}$. Robbins, 2013). According to Robbins there are some questions to read the culture of work in an organization (S. P. Robbins \& Coulter, 2016), consists of as follows:

\section{a. Exploring Background Checks}

From the examination of the website of the Ministry of Religious Affairs and websites several Working Group area, the display of Web pages has been standardized from the central Religious Ministry. Besides showing information activities and important news abou religious affairs, each website prements five, values of working culture, $\mathrm{t}^{\mathrm{t}} \mathrm{decl}$ of illegal levy and grat catio winthe movement of the men revolt. $n$ and the harmony of ig is peo and promoting nat nalism. $\mathrm{s}$ me websites are such as strict Areas Ministry of Religiou Affa of Central Java Province ap mm. Minis of $\mathrm{P}$ igious Affairs in Dema Dist toes not display the Cor menu on its bsite.

his Ministry's related news lately is about corruption cases in the Ministry of Religious Affairs. The most popular news is the hand capture operation by Corruption Eradication Commission known as $K P K$ related to the selection process of the Ministry of Religious institutions. The party chair of the Minister of Religious Affairs was held to organize positions in central and Ministry of Religious Affairs local. In addition, rerevealed in the media of corruption cases in the previous Ministry of Religion, the former Minister of Religious Affairs of President Megawati, Said Agil Husein Al Munawar, convicted by the Assembly of Judges by State Court of Central Jakarta in 2006 ago. Corruption procurement of the Qur'an laboratory equipment Madrasain 2012, and the misuse of BPI ancm he operational fund of minister tho dragge the name of the Min ar or Religiou Affairs, Suryadharn Ali in 20 Tribunnews accesse 15 ay 2019).

Forme rien Min try Religious Affairs, M Ja stated, M Minister of

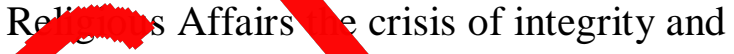
isis adherence to tne prevailing rules. If official stated this according to the S ndard $f$ erating Procedure. Jasin was apponmed in 2012-2016 at Inspectorate On of ministry of Religious Affairs, after he was no longer there, he taught more officials who get promotion in the neighborhood at Ministry of Religious Affairsis the people who once had precisely a discipline strike because of a number of Violation.

\section{b. Observing the physical environment and the corporate symbols}

The Ministry of Religious Affairs has a "charity sincere" logo written on the organization's emblem. The State Apparatus appearance and dress pay attention to their respective religious teachings. 
The State Apparatus areworking in the Ministry of Religious Affairs is regarded by society as a religious figure or a person who understands religious matters.

From the openness between the Offices, the Ministry of Religious Affairs is still "no distance" between the task executors Unit. Ministry of Religious Affairs building dominated by green color, in Islamic teachings green color is the preferred color of Prophet Muhammad after the color white. Worship facilities are very well built in the office area. Ministry of Religious Affairs generally has a sports field. This physical condition reflects that the Ministry of Religious Affairs is a religious institution.

\section{c. How do you classify people you meet}

Civil apparatus of the Ministry of Religious Affairs that I have encountered mostly be formal and keep myself in providing information. The organization hierarchy looks strict. This indicates tha the organization is a type hierarchy.

d. Observing the ridand if Human Resource rs vization elf (if has)

Fror the obs rvation, the Ministry of Religious ff $s$ does not provide specific int $R$ vurce guidance to the minis $y$, wh includes the code of o actr.mment development is based o. rovernment Regulation No. 53 in 2010. This dicates that there is no claim on the State Apparatus at Ministry of Religious Affairs, which differs from other ministries of the employment Regulation.

\section{e. Asking questions about people you meet}

From the interview, the Ministry of Religious Affairs imposed an open bidding for Echelon 1 and Echelon 2 beginning in 2018. As for Echelon 3 and 4 has not been treated merit system. From one of the informant, for Echelon 3 and 4 is still based on consideration like and dislike of superiors. From the results of interviews with the head of Research and Development of the Ministry of R liaious Affairs that research Data fro Resear. and Development provides overviev that the leadership of $\mathrm{ch}$ of th Minist of Religious Affair anits ho two c ofte sides Back. Aplo ation af merit system in rs of rec tmer placement and promotio of emp sees who are jud not to ay attention to the ompetency aspect, resulting in employees ho are i a certain position has no c. apetenc and to take care of the indüstry.

From the explanation above, it is concluded that the Ministry of Religious Affairs has not fully implemented the merit system in its promotional process. Of these five, the culture of the Ministry of Religious Affairs can be concluded, namely the Ministry of Religious Affairs is an institution that needs attention in integrity, institutions with a type of cultural hierarchy, religious, and yet to fully implement the merit of the system.

The development of the working culture in the Ministry of Religious Affairs has a strategic role to fix the working culture of the institution. On the other hand, the culture of the previous real organization when contrary to new cultural values can lead to resistance. 
This needs to be identified seriously so that the implementation of the cultural value of work reaches the goal.

\section{CONCLUSION SUGGESTION}

AND

Based on the results of the field findings can be concluded as follows:

1. Ministry of Religious Affairs is a vertical institution with the working units, which are 4543 units of work. The record of accomplishment of integrity issues makes changing mindsets and culture set the State Apparatus of Ministry Religious Affairs as urgent necessity.

2. The Ministry Religious Affairs has not developed a structured, comprehensive and sustainable work culture. Implemetation 5 Cultural values of the Ministry

Religious Affairs in the implementation have nided the Regulation of Minist of Administrative

Reform Num 39 in 242 .

3. Factors that influenco the imr mentation of five cultural ues work in the Ministry of Re us Affa's are as follows:

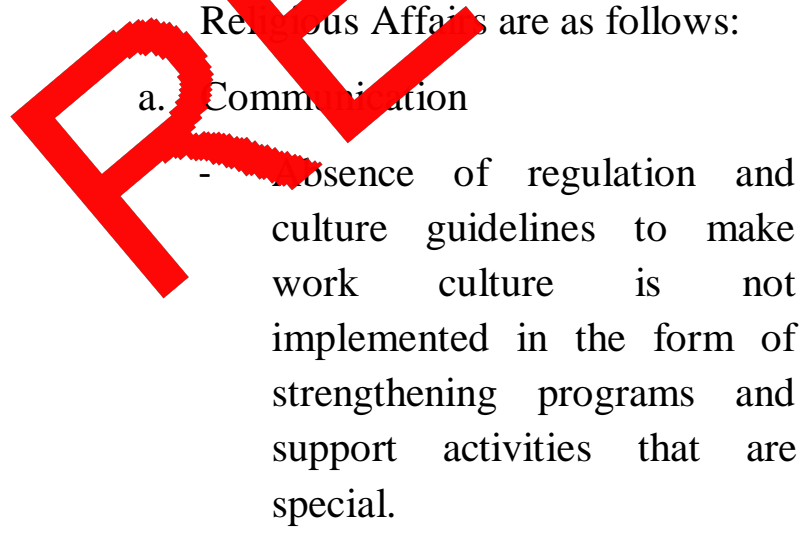

- In the formulation of the value of culture, work at Ministry of Religious Affairs is through formulating measurement of key behavior. Ministry of Religious Affairs also does not make regulations related to the socialization or internalization process and evaluation.

- Five cultural values of work are understood differently by State Apparatus of Minictmon of Religious Affairs and considered as salng r mere.

- The abs ce of op atio indicato and nstrumes to objec ve and have the objea ve and measurable standar in carrying out the five cultural values of work, king it difficult to do objective assessments by the leadership of the implementation of five cultural values of work by aState Apparatus individual.

b. Resources

- A legally structural reform team is in the central of Ministry of Religious Affairs. The structure of bureaucratic reform team at the district level is still only an additional task. In addition, at the district level has not implemented a program that is the task of bureaucratic reform team function. 
- Ministry of Religious Affairs has not implemented the delegation of implementation authority and budget support, as well as other supporting facilities. So the implementation of the cultural value of work does not run systematically.

\section{c. Commitment and Leadership}

The development of work culture in Ministry of Religious Affairs has not been a priority scale. In addition, the Ministry of Religious Affairs opinion that internalization of work culture is not done in a cohersive, making the development of work culture understood only as a mere and jargon. Even in List Contents of Budget, known as DIPA was not estimated the development program of workat Ministry of Religious Affairs

\section{d. Organizational Culture}

The Ministry of Religio Affà s of worling culture is in fact an stitu buthat needs attention in srity, stitutions with a type of cul a ierarchy, ligious, and yet to lly imp nent the merit system. $T$ culture is in contrary to the valu of th working culture declared th mman and ressionalism. This affect he in the value of cult mmmark in the Ministry of Religious airs.

\section{Suggestions:}

According to the research resultsabove, the advice for the Ministry of Religious Affairs are as follows:
1. The Ministry of Religious Affairs issued a structured and comprehensive regulation on the work culture that includes the implementation of the working culture in which it includes a valuation indicator of occupational culture.

2. Planning, implementing socialization and internalize 5 cultural values of work on all State Apparatus of Ministry of Religious Affairs so that there mindset and culture $s$

3. Developing an imp nentatio strategyof $t^{t}$ cultural ue of work in is ase invuving reser 1 and o elopm agency, nat he policy Ministry of Religious ffairs is ongoing based on the orga zation necessity. The resu" should be considered in vari is policies of the Ministry of gious Affairs.

Empowering the bureaucracy reform team at each level in order to implement the delegation of implementation authority and budget support, it is as well as other supporting facilities.

5. The Ministry of Religious Affairs enforces merit system at all levels of Echelon position and assesments the office so that the leader in the Ministry of Religious Affairs consists of individuals who are integrity, professional, innovative, responsible and exemplary Religious values of the Ministry of Religion.

6. Recruiting new employees with a culture-oriented value of organizational work 


\section{REFERENCES}

Arianto, A., Zauhar, S., \& Hanafi, I. (2015). Faktor-Faktor Yang Mempengaruhi Implementasi Program Pengembangan Budaya Kerja Di Sekretariat Daerah Kabupaten Pati, 5(1), 204-217.

Bang, C. A. D., Kusuma, A. R., \& Utomo, H. S. (2014). Kajian Budaya Kerja Dalam Kabupaten Kutai Barat, 2(3), 2089-2101.

Crews, D. (2013). Aligning Culture with Human Resource Strategies, 4(15), 71-75.

Denzin, N. K., \& Lincoln, Y. S. (2000). Handbook of Qualitative Research. California: Sage Publication.

Hanaysha, J. (2016). Examining the Effects of Employee Empowerment, Teamwork, and Employee Training on Organizational Commitment. Procedia - Social and Behavioral Sciences, 229, 298-306. https://doi.org/10.1016/j.sbspro.2016.07.140

Hill, H. C. (2003). Understanding Implementation: Street-Level Bureaucrats' Resources for Reform. Journal of Public Administration Research and Theory, 13(3), 265-282. https://doi.org/10.1093/jopart/mug024

James, P. S. (2014). Aligning and Propagatin Organizational Values. Procedia Economic and Finance, 11(14) 109 . https://doi.org/10.1016/S22 5671(14)00180-4

Jodi, S., \& Stephan M. (201 Effective Implementatio in Practice grating Public Po $\mathrm{P}^{\prime}$ and Mana ment. USA: Jossey Bass.

Kadarisma M Junawan, A., \& Ismiyati, I. 017). mplemen si Kebijakan Sistem I) nsport arat Dan Dampaknya xhadap $\mathrm{K}$,jahteraan Sosial Di Jakarta. Jurnammmanajemen Transportasi Dan Logistik. ttps://doi.org/10.25292/j.mtl.v2i1.129

Kementerian Agama RI. (2017a). Kementerian Agama dalam Angka 2016 Ministry of Religius Affairs in Figures 2016. Jakarta.

Kementerian Agama RI. KMA 582 Tahun 2017 (2017).

Kementerian Agama RI. (2019). Laporan Kinerja
Kementerian Agama 2018. Jakarta.

KPK. (2015). Integritas Sektor Publik Tahun 2014 Fakta Korupsi dalam Layanan Publik. Jakarta: Direktorat Penelitian dan Pengembangan Kedeputian Bidang Pencegahan Komisi Pemberantasan Korupsi.

Lawler III, E. E., \& Worley, C. G. (2006). Designing Organizations That Are Built to Change. MIT Sloan Management Review.

Lerner, M. P. (1982). Stress at the workplace. Issues in Radical Therapy.

Malik, M. S., \& Tariq, S. (2016). Impact of Spiritual Intelligence on Orgamional Performance. International review of Management and Marketing, 2), 289-297.

Mattila, M. (2008). $\mathrm{Va}^{\mathrm{l}} \mathrm{s}$ in o nization difficult to $y$ rstand, impo bo internalize? Soc Re nsibility durnal, $4(1 / 2), 24-33$. https. o rg/10.1108, 47 , 0810856802

Nugroho Riant. (2 7). Public Policy (6th ed.). manarta: PT Elex Tedia Komputindo.

sman-gani, *. M., Hashim, J., \& Ismail, Y. (2007). fects of Religiosity , Spirituality, and rsonal Values on Employee rerrormance: A Conceptual Analysis, (2003).

Robbins, S. (2013). Organizational Behavior. Zhurnal Eksperimental'noi i Teoreticheskoi Fiziki. https://doi.org/10.12737/4477

Robbins, S. P., \& Coulter, M. (2016). Management. England: Pearson Education Limited.

Sabatier, P., \& Mazmanian, D. (1980). The Implementation Of Public Policy . Policy Studies, Januari(4), 538-560.

Sani, S. I. A., Mohammed, A. H., Misnan, M. S., \& Awang, M. (2012). Determinant Factors in Development of Maintenance Culture in Managing Public Asset and Facilities. Procedia - Social and Behavioral Sciences, 65(ICIBSoS),

827-832. https://doi.org/10.1016/j.sbspro.2012.11.206

Signé, L. (2017). Policy Implementation - A Synthesis of the Study of Policy Implementation and the Causes of Policy Failure. $O P C$ Policy Center, PP17/03(March), 9-22. 
Smith, M. E. (2003). Changing an organisation's culture: correlates of success and failure. Leadership \& Organization Development Journal, 24(5), 249-261. https://doi.org/10.1108/01437730310485752

Sugiyono. (2014). Metode Penelitian Kuantitatif, Kualitatif dan $R \& D$. Bandung: Alfabeta.

Van der Voet, J. (2014). The effectiveness and specificity of change management in a public organization: Transformational leadership and a bureaucratic organizational structure. European Management Journal, 32(3), 373382.

https://doi.org/10.1016/j.emj.2013.10.001

Warrick, D. D. (2017). What leaders need to know about organizational culture. Business Horizons, 60(3), 395-404. https://doi.org/10.1016/j.bushor.2017.01.011

Widodo, J. (2007). Analisis Kebijakan Publik. Malang: Bayumedia Publishing.

Wihantoro, Y., Lowe, A., Cooper, S., \& Manochin, M. (2015). Bureaucratic reform in post-Asian Crisis Indonesia: The Directorate General of Tax. Critical Perspectives on Accounting, 31, 44-63.

https://doi.org/10.1016/j.cpa.2015.04.002

Yaghi, A., \& Al-Jenaibi, B. (2018). Happiness Morality, Rationality, and $\mathrm{Cb}$ mes in Implementing Smart Gove nent olicy. Public Integrity, 2 2, 299. https://doi.org/10.108 0999 o17.150m 947

Yuan, C.-K., \& Iee, C.-Y. ( 1). Explorwion of a constru model linking eadership types, org? Lation cy ure, emplo,es performance and ade $1 \mathrm{p}$ performance. Procedia 1 .

alal Behay al Sciences, 25, 123ins://doi.or 10.1016/j.sbspro.2011.10.534

nuri, A. (2016). Strategi Penerapan Lima Nilai Budaya Kerja di Kementerian Agama Nenuju Pelayan Prima. Median-Te: Jurnal Studi Islam, 14(1), 1-14. 